DOI https://doi.org/10.18551/rjoas.2017-04.29

\title{
INVESTIGATION AND STUDYING OF THE BIOCHEMICAL EFFECT OF CAROTENE DYESTUFF MATERIALS AND CAPSAICIN IN SPECIAL SPICE PEPPER (CAPSICUM ANNUUM CONVAR. LONGUM L.) VARIETIES
}

\author{
Lantos Ferenc*, Fári Fanni, Györgyi Emese \\ Plant Sciences and Environment Protection Institute, University of Szeged, Hungary \\ *E-mail: lantos@mgk.u-szeged.hu
}

\begin{abstract}
"The investigation of sweet pepper must not be stopped since there are still many research results hiding in the sweet pepper bell", claimed Albert Szent-Györgyi Nobel prize biologist, physician-researcher referring to the possibilities of subsequent researcher generations. It is a national tradition in Hungary to grow and breed pepper ("paprika", Capsicum annuum convar. longum L.), which is the vegetable covering the largest growing area around Szeged and Kalocsa cities. In addition, the vitamin $\mathrm{C}$ content of the pepper, the capsaicin, and also the carotenoids and fructose can be found in high concentration in the bells. The capsaicin and carotene have a prominent role in scientific literature, as their production, physiological effect and pharmacological applicability started a number of research works both in Hungary and in the world. In the first period of our research we analyzed the concentration of carotene dyestuff materials (ASTA) and capsaicin in different bell pepper and cherry shaped pepper (Capsicum annuum convar. cerasiforme L.) varieties. Then, we made a forage-mix for laying hens. Having finished the foraging programme we started the laboratory control of changing the carotene dyestuff material of egg yolk. Our results demonstrated that the mixed pepper powder in forage is suitable to increase the concentration of the carotene dyestuff material of the egg yolk. It will be a new alternative for the application of pepper powder in the future.
\end{abstract}

\section{KEY WORDS}

Carotene dyestuff, capsaicin, egg yolk, ASTA, Capsicum annuum convar. longum L.

Numerous varieties of Hungarian spice peppers (Capsicum annuum convar. longum L.) and cherry shaped hot peppers (Capsicum annuum convar. cerasiforme) are well known but the carotene dyestuff material and capsaicin content of these species and hybrids are significantly different. The ß-carotene, ß-carotene-monoepoxid, indicator chrome, neo-ßcarotene $B$ and $U$, violaxanthin, xantofill, neoxanthin, leaf xanthine, leaf chrome, and anteraxanthin give the colour of the carotene dyestuff material of spice peppers even in the raw, green stage of the plant. In addition to these, in the ripe stage of the plant, the autochromium, criptosanthin, capsorubin, capsanthin, xanthophyll-epoxide, zeaxanthin and their cis-isomers also contribute to the red colour development of the pepper bells. Thus the development of red colour in paprika bells is induced by zeaxanthin $\left(\mathrm{C}_{40} \mathrm{H}_{56} \mathrm{O}_{2}\right)$, by capsanthin $\left(\mathrm{C}_{40} \mathrm{H}_{56} \mathrm{O}_{3}\right)$ formed with the addition of water and after ring-opening, and capsorubin $\left(\mathrm{C}_{40} \mathrm{H}_{56} \mathrm{O}_{4}\right)$ (Figure 1).

The quality of spice pepper powder is determined by the carotenoids and other dyestuff materials. All these are collectively called carotene dyestuff material. The concentration of carotene dyestuff material is determined by the ASTA (American Spice Trade Association) value. Based on the quality of their carotene dyestuff material, the Spice pepper powders can be classified into the following categories: Special (Premium quality): homogenous grain, uniform, correct grinding (up to $0.5 \mathrm{~mm}$ sieve size), deep red colour, spicy fragrance and sweet taste, $\Sigma$ - carotene dyestuff material is over 120 ASTA; Delicate (First class): homogenous grain, uniform, adequate grinding fineness, red or yellow-red base colour with a yellow-brownish tinge, characteristic aroma and taste, $\Sigma$ - carotene dyestuff material is between ASTA 100-120; Sweet Noble (Precious): homogenous grain, slightly mosaic-like appearance, appropriate grinding fineness, lighter red colour, with a slightly yellow-brownish tinge, characteristic aroma and taste, $\Sigma$ - carotene dyestuff material is between ASTA 80-100; 
Rose (Medium quality): homogenous grain, slightly mosaic-like appearance, appropriate grinding fineness, light red base colour with a yellow-brownish tinge, characteristic aroma and flavour, slightly spicy, $\Sigma$ - carotene dyestuff material is between ASTA 60-80 (XC. Law of 1995. and decree issued for its implementation 1/1996. (I. 9.) FM-NM-IIA).

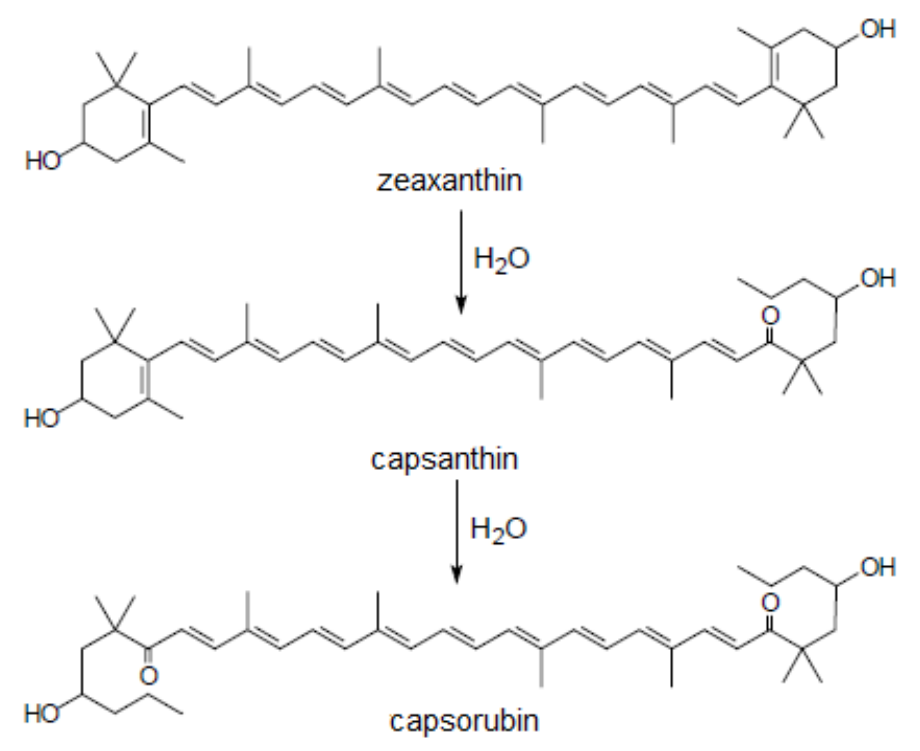

Figure 1 - The process of zeaxanthin, capsanthin and capsorubin development in spice pepper (Deli, 2000)

Capsaicinoids $\left(\mathrm{C}_{18} \mathrm{H}_{27} \mathrm{O}_{3} \mathrm{~N}\right.$, 8-methyl-N-vanillyl-6-nonenamide $)$ are the pungent materials of spice and hot peppers. From biological perspective they are plant alkaloids (Högyes, 1878). Only the Capsicum genus is capable of producing these compound groups. We feel it hot because primarily it stimulates sensory nerves, that is, it has an effect on sensory neurons bound to special capsaicin-sensitive molecules (TRPV1 / VR1) (Jancsó et al., 1967; Szolcsányi, 2004).

Table 1 - The most common capsaicinoids (Fujiwake et al, 1980)

\begin{tabular}{|c|c|c|c|c|}
\hline Capsaicinoid name & Abbrev. & $\begin{array}{c}\text { Typical relative } \\
\text { amount }\end{array}$ & $\begin{array}{c}\text { Scoville heat } \\
\text { units }\end{array}$ \\
\hline Capsaicin & $\mathrm{C}$ & $69 \%$ & $16,000,000$ \\
\hline Dihydrocapsaicin & $\mathrm{DHC}$ & $22 \%$ & $15,000,000$ \\
\hline Nordihydrocapsaicin & NDHC & $7 \%$ & $9,100,000$ \\
\hline Homodihydrocapsaicin & HDHC & $1 \%$ & $8,600,000$ \\
\hline Homocapsaicin & HC & $1 \%$ & $8,600,000$
\end{tabular}


Both the properties of pepper species and the breeding can collectively determine the quantity and quality of capsaicinoids measured on the Scoville-scale. There are also some wild species of pepper, which can contain up to $600-900 \mathrm{mg} / 100 \mathrm{~g}$ capsaicin. Capsaicinoids are dichotomous, long-chain $\mathrm{C} 9-\mathrm{C} 11$ fatty acids; they develop from phenylalanine $\left(\mathrm{C}_{9} \mathrm{H}_{11} \mathrm{NO}_{2}\right)$ vanillilamin or leucine $\left(\mathrm{C}_{9} \mathrm{H}_{13} \mathrm{NO}_{2}\right)$ during the biological ripening of the plant (Pino et al., 2006).

The investigation of the effect of the capsaicin, extracted and crystallized from hot pepper, on sensory neurons of the mammalian species was carried out by (Savidge et al., 2002) in guinea pigs, (Gavva et al., 2004) in rabbits and (Phepls et al., 2005) in dogs. The effect of spice pepper powder changing the quality of the egg yolk was first observed by Benedek (1937) in Hungary. Then Gonzales et al. (1999) used hot spice pepper powder mixed in the forage. They found that $5.26 \mathrm{mg} / \mathrm{kg}$ capsaicin content in the forage-mix had significantly increased the incorporation of carotene dyestuff material in egg yolk, compared with the effect of forage-mix without capsaicin. Our aim was to investigate the effect of carotene dyestuff material and capsaicin on several spice and cherry shaped pepper variety powders of Duna-R Ltd, seeds breeder and distributor company, regarding the incorporation and change of carotene-materials in egg yolk.

\section{MATERIAL AND METHODS OF RESEARCH}

The aim of the research was to investigate the effect of carotene dyestuff (astaxantin) and capsaicin content of sweet peppers on the change of carotenoid materials of egg yolk.

In the first part of the work the amount of carotene dye stuff and capsaicin materials of hot and sweet pepper powders was determined. 18 sweet and 33 hot pepper powders were investigated for carotene dyestaff. Out of the hot pepper species 21 belong to spice peppers (Capsicum annuum convar. longum L.), while 12 hot peppers belong to cherry shaped varieties (Capsicum annuum convar. cerasiforme L.). The powder samples were investigated by the Laboratory of the University of Szeged Faculty of Medicine, Hungary in March-April of 2016. The determination of the carotene dyestuff was carried out by a local method of MSZ 9681-5:2002 with Shimadzu UV-1800 spectrophotometer. The determination of capsaicin concentration was carried out by a local method MSZ 9681-4: 2002 also with Shimadzu UV1800 spectrophotometer.

In the second part of our research a forage mix for laying hens was compiled. The basis of the forage mix was maize grist. During every feeding $100 \mathrm{~g}$ maize grist was mixed with $2 \mathrm{~g}$ powder. This method was carried out in tree repeats. The first feeding was $100 \mathrm{~g}$ forage and $2 \mathrm{~g}$ sweet spice pepper powder, the second feeding was $100 \mathrm{~g}$ forage and $2 \mathrm{~g}$ hot spice pepper powder and the third feeding was $100 \mathrm{~g}$ forage and $2 \mathrm{~g}$ cherry shaped hot pepper powder. In case of the intensive laying hens the time of the generation of an egg, under healthy neurohormone and daylight condition is usually 25-26 hours (Szalay, 2002). Therefore, the eggs were collected after 1-week continuous feeding. The egg yolk was investigated by the Laboratory of the University of Pécs, Institute of Pharmacognosy. The determination of the carotenoid materials in eggs was carried out by the method of LC(APCI)MS HPCL (Schlatteret and Breithaupt, 2006). Our examinations were carried out in three repeats.

\section{RESULTS OF RESEARCH}

The results of carotene dyestuff and capsaicin concentration powder samples. Laboratory investigations found that the quality of each sweet spice pepper powder met the requirements of first class. The amount of carotene dyestuff exceeded the 120 ASTA in every sample (Diagram 1). The quality of hot spice pepper powders was prominent as well, although out of these there were five samples where the amount of carotene dyestuff was

below the expected 120 ASTA (Diagram 2). Regarding the capsaicin concentration, out of the cherry shaped hot pepper powders (Diagram 3) three samples did not meet the 
requirements of the standard of Hungarian Certification $(0.2 \mathrm{mg} / \mathrm{g})$. Naturally, human senses can perceive them hot all the same.

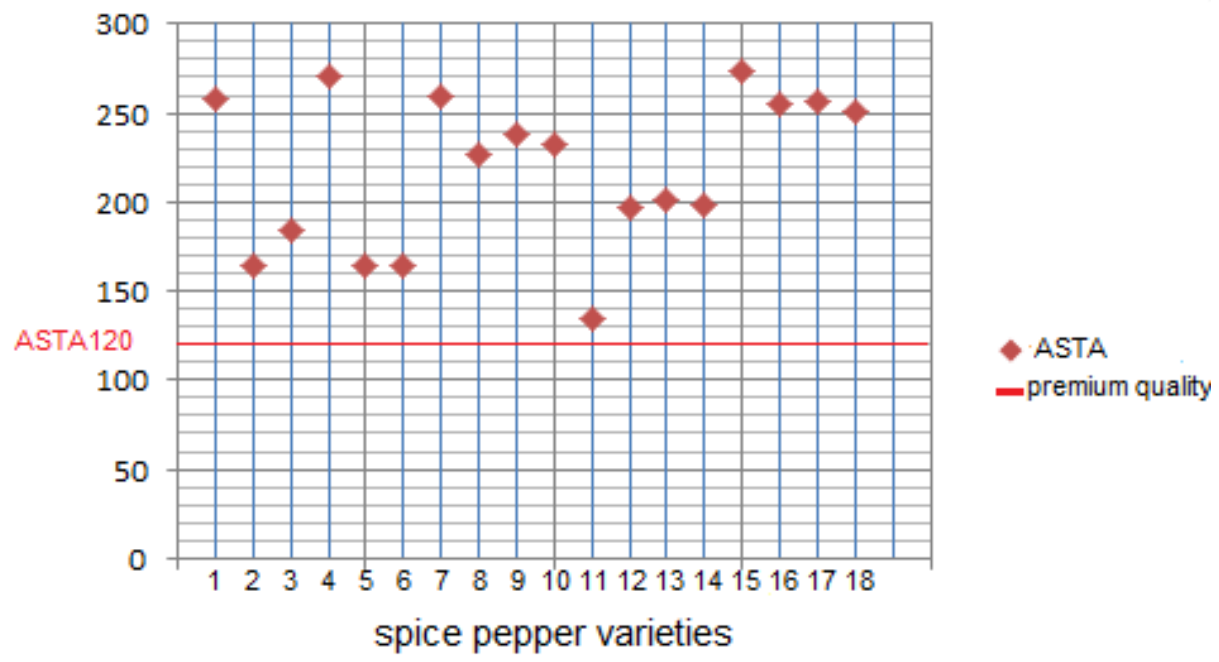

Diagram 1 - Carotene dyestuff amount of sweet spice pepper powder samples (ASTA)

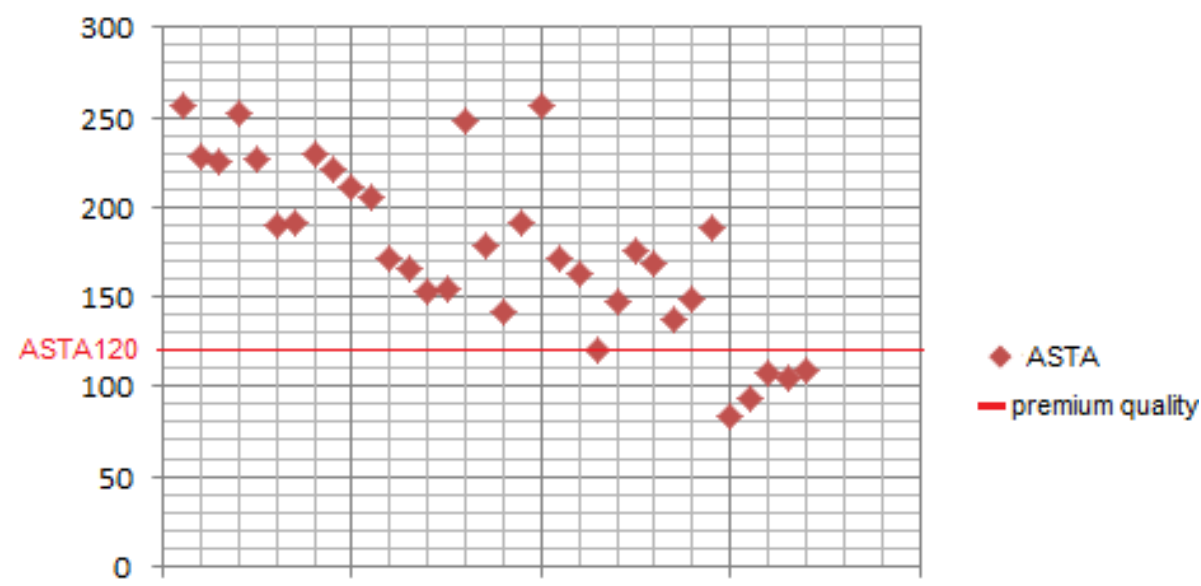

spice pepper varieties $1-33$.

Diagram 2 - Carotene dyestuff amount of hot spice pepper powder samples (ASTA)

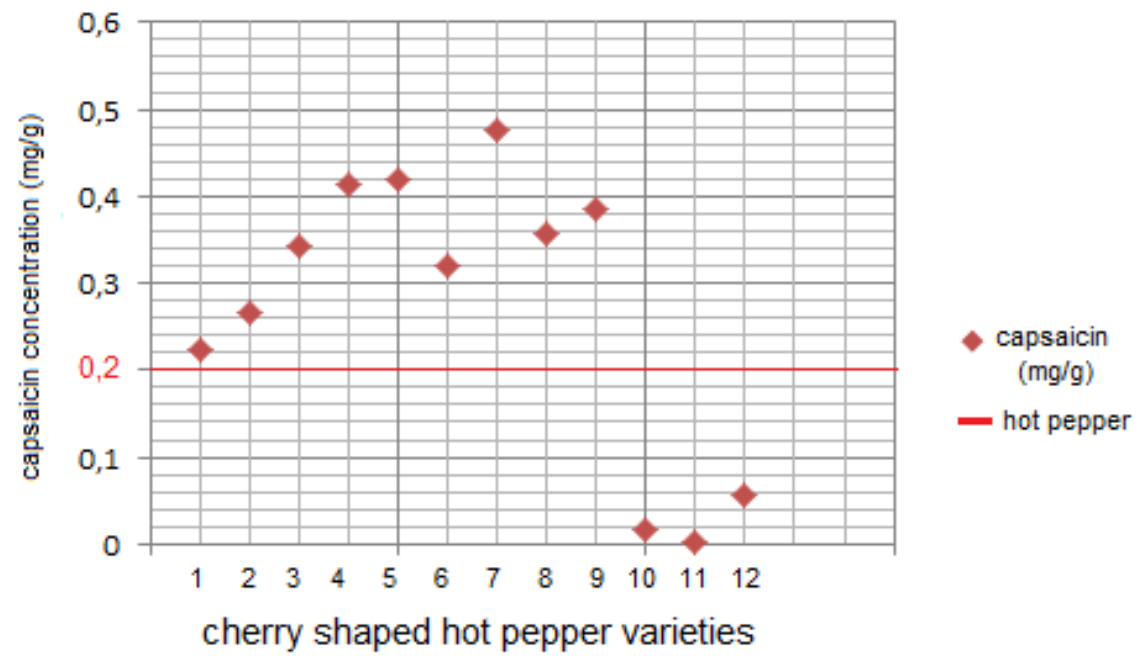

Diagram 3 - Capsaicin amount of sherry shaped hot pepper powder samples $(\mathrm{mg} / \mathrm{g})$ 
Among the results the capsaicin concentration of hot spice pepper powder samples great differences could be observed. Most samples did not meet the expectations; however, their carotene dyestuff ASTA amount was similar to the standards of first class (Diagram 4).

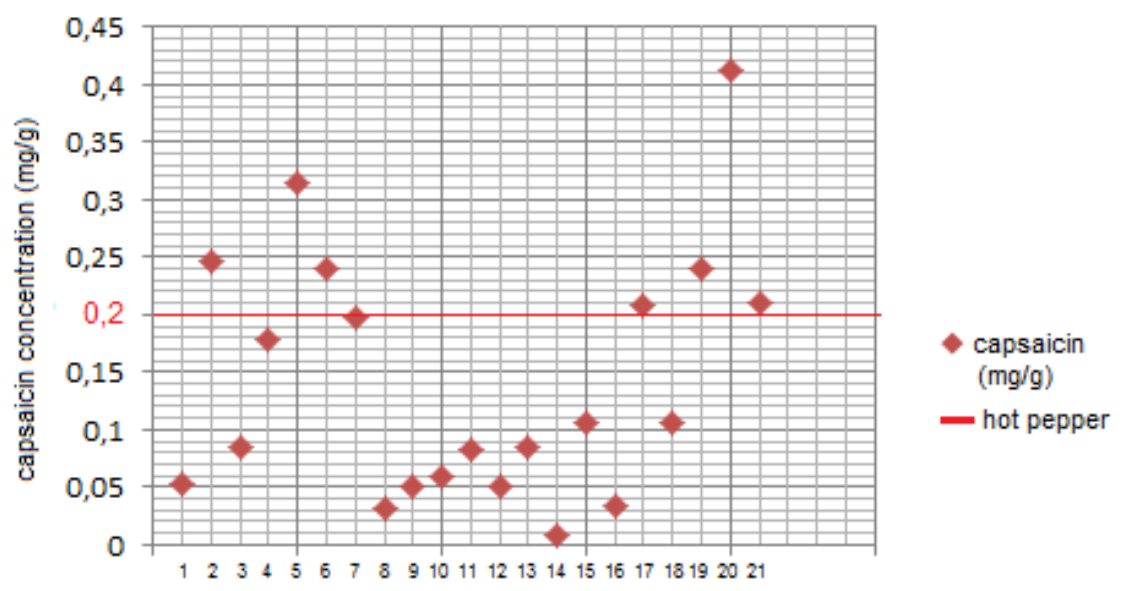

hot spice pepper varieties

Diagram 4 - Capsaicin amount of hot spice pepper powder samples $(\mathrm{mg} / \mathrm{g})$

The results of the egg yolk carotenoid investigation. The chromatograph analysis focused on nine previously known carotenoid-compounds and the amount of total carotene $(\Sigma$ carotene) in the egg yolk. Their amounts were determined based on triplicate measurements during our research, but the applied chromatograph system showed four (carotene 1;2;3;4) unknown, orange coloured carotenoid materials as well (Table 2). Furthermore, an unknown structured, red coloured carotenoid was also discovered in the egg yolk.

Table 2 - Carotenoid materials of egg yolk

\begin{tabular}{|c|c|c|c|c|}
\hline \multirow{2}{*}{ carotenoid } & \multicolumn{4}{|c|}{ Carotenoid, \% } \\
\cline { 2 - 5 } & $\begin{array}{c}\text { Control forage } \\
\text { only }\end{array}$ & $\begin{array}{c}\text { Hot pepper powder } \\
\text { and forage }\end{array}$ & $\begin{array}{c}\text { Sweet pepper powder } \\
\text { and forage }\end{array}$ & $\begin{array}{c}\text { Cherry shaped pepper } \\
\text { powder and forage }\end{array}$ \\
\hline neoxanthine & traces & 0.8 & 0.7 & traces \\
\hline violaxanthine & 1.7 & 2.1 & 1.7 & 1.8 \\
\hline anteraxanthin & 7.8 & 8.5 & 3.6 & traces \\
\hline$(13 / 13$ 'Z) lutein & traces & 1.9 & traces & 63.8 \\
\hline lutein & 63.3 & 58.0 & 63.6 & 17.5 \\
\hline zeaxanhtine & 14.1 & 22.5 & 21.4 & traces \\
\hline unknown red & traces & traces & traces & 1.0 \\
\hline$\alpha$-criptoxanthine & traces & 0.2 & traces & traces \\
\hline echinenon & traces & traces & 2.5 & 1.6 \\
\hline$\beta$-criptoxanthine & traces & 0.8 & 1.4 & 1.7 \\
\hline carotene 1. & 3.5 & 1.2 & 1.1 & 2.6 \\
\hline carotene 2. & 3.1 & 0.9 & 1.1 & 3.0 \\
\hline carotene 3. & 3.5 & 2.1 & 1.7 & 2.0 \\
\hline carotene 4. & 2.7 & 1.6 & 1.2 & 3.3 \\
\hline $\begin{array}{c}\text { carotene } \\
\text { (mg/g) }\end{array}$ & 0.9 & 4.8 & & \\
\hline
\end{tabular}

The data of table 2 can show that the carotene dyestuff materials and capsaicin had influence on the production of the unknown carotenoids. Our investigation also found that the carotene dyestuff materials and capsaicin together affected the zeaxanthine production and the total carotene content of egg yolk. It is very interesting because zeaxanthine is mostly produced in maize. Affected by spice pepper powders, the amount of total carotenoids of egg yolk in case of hot spice pepper powder supplement increased by 5.3 times, in case of sweet spice pepper supplement by3.6 times and in case of cherry shaped pepper powder supplement by 2.2 times, compared to maize forage nutrition. 


\section{CONCLUSION}

Based on the detected concentration of the carotene dyestuff of spice pepper varieties it was found that the growing conditions on the South Plain are perfect for spice pepper cultivation. The carotene dyestuff and capsaicin content of almost all of the controlled varieties met the quality requirements. The capsaicin content of cherry shaped hot pepper varieties referred to excellent quality. Unfortunately, the capsaicin content of hot spice pepper was satisfactory only for few of the varieties; therefore, we considered only the selected varieties suitable for cultivation. Based on the detected carotene dyestuff and capsaicin content of we could declare that a total selection will be necessary in case of all the three varieties in the future!

The results of the impact investigation of the spice pepper powders considering the carotenoid composition of egg yolk was surprising and it also had novel scientific results. The photometer examination revealed five previously unknown carotenoid compositions, which will need further investigation. It was a very surprising result that the zeaxanthine content of egg yolk showed higher values when feeding spice pepper powders than in case of feeding maize. This fact is important because zeaxanthine has got a decisive role in the development of eyesight of humans. However, the spice pepper powders did not affect the increase in lutein production. The outstanding result of our investigation was that the carotene dyestuff in spice pepper powder and also the capsaicin could increase the total carotene ( $\Sigma$ carotene) of egg yolk very significantly.

To sum up, it can be declared that the selected spice pepper powders are suitable for natural carotene supplement of forage for laying hens to increase the amount of the carotenoid materials in egg yolk. The carotenoid-rich egg yolk, for example, better promotes the development of the eyesight of children, and it will be absorbed in the form of essential antioxidants in human body. Using spice and cherry shaped pepper powder as natural feed supplements could be an alternative process to increase the spice pepper growing area in Hungary, which reduced from 6000 ha to 1500 ha in the past fifty years.

\section{ACKNOWLEDGEMENTS}

We would like to thank to the colleagues of the University of Szeged Faculty of Medicine and the University of Pécs Institute of Pharmacognosy.

\section{REFERENCES}

1. Benedek, L. (1937): A tyúktojás sárgájának festése paprikaetetés útján. Különlenyomat a Kisérletügyi Közlemények XL. (1937.) kötete 1-6. füzetéből M. Kir. Mezőgazdasági Vegykisérleti és Paprikakisérleti Állomás, Szeged Hungary.

2. Deli, J. (2000): Paprika karotinoidok vizsgálata: analizis, izolálás, szerkezetazonositás. ÁOK. Akadémiai Doktori Értekezés. University of Pécs, Institute of Medicine Chemistry. 6. p.

3. Fujiwake, H.- Suzuki, T.- Oka, S.- Iwai, K. (1980). "Enzymatic formation of capsaicinoid from vanillylamine and iso-type fatty acids by cell-free extracts of Capsicum annuum var. annuum cv. Karayatsubusa". Agricultural and Biological Chemistry. 44: 2907-2912 pp.

4. Gavva, N.R.- Klionsky, L.- Qu, Y.- Shi, L.- Tamir, R.- Edenson, S.- Zhang, T.J.Viswanadhan, V.N.- Toth, A.- Pearce, L.V.- Vanderah, T.W.- Porreca, F.- Blumberg, P.M.- Lile, J.- Sun, Y.- Wild, K.- Louis, J.C.- Treanor, J.J. (2004): Molecular determinants of vanilloid sensitivity in TRPV1. J. Biol. Chem. 7;279(19):20283-95 pp.

5. Gonzalez, M.- Castano, E.- Avila, E.- Gonzalez de Mejia, E. (1999): Effect of capsaicin from red pepper (Capsicum sp) on the deposition of carotenoids in egg yolk. Journal of the science of food and agriculture. 79 (13) pp. 1904-1908 pp.

6. Hőgyes, E. (1878): Beitrage zur physiologischer Wirkung der Bestandteile des Capsicum annuum. Arch. Exp. Pathol. Pharmacol. 9: 117-130 pp. 
7. Jancsó, M.- Jancsó, G. A.- Szolcsányi, J. (1967): Direct evidence for neurogenic inflammation and its prevention by denervation and by pre-treatment with capsaicin. $\mathrm{Br}$. J. Pharmacol. Chemother. 31: 138-151 pp.

8. Pino, P.E.- Sauri-Duch, and Mabot, R. (2006): Change in volatile compounds of Habanero chili pepper (Capsicum chinense Jack. Cv. Habanero) at two ripening stages. J. Food.Chem., 94: 394-396 pp.

9. Phelps, P.T.- Anthes, J.C.- Correll, C.C. (2005): Cloning and functional characterization of dog transient receptor potential vanilloid receptor-1 (TRPV1). European Journal of Pharmacology. 513 (1-2): 57-66 pp.

10. Savidge, J.- Davis, C.- Shah, K.- Colley, S.- Phillips, E.- Ranasinghe, S.- Winter, J.Kotsonis, P.- Rang, H.- Mclntyre, P. (2002): Cloning and functional characterization of the guinea pig vanilloid receptor 1. Neuropharmacology.;43:450-456 pp.

11. Schlatterer, J.- Breithaupt, E.D. (2006): Xanthophylls in commercial egg yolks. Quantification and identification by HPCL and LC(APCI)MS using a C30 phase. J. Agric. Food Chem.: 54. 2267-2273 pp.

12. Szalay, I. (2002): Old Hungarian poultry in the 21th century. Mezőgazda Kiadó, Budapest. ISBN 9789632867175.

13. Szolcsányi, J. (2004): Forty years in capsaicin research for sensory pharmacology and physiology. Neuropeptides 38: 377-384 pp. 